\title{
O demônio nos "paraísos artificiais": considerações sobre as políticas de comunicação para a saúde relacionadas ao consumo de drogas
}

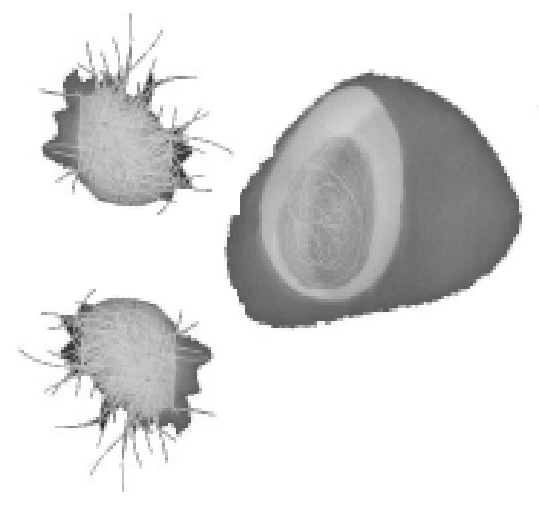

Mônica Benfica Marinho'

MARINHO, M. B. The devil in "artificial paradises": thoughts on healthcare communication policies regarding drug consumption. Interface - Comunic., Saúde, Educ., v.9, n.17, p.343-54, mar/ago 2005.

The phenomenon of drug consumption in contemporary society is the theme of broad discussions. Regarding healthcare communication policies in Brazil, there is a blatant lack of regard for the constitutive dimensions of this phenomenon. As a result, conduct related to the prevention of drug consumption involves the said consumption in marginal significances that, far from fostering a sensibility to behavioral change, generate prejudice against and segregation of the user. This can be seen in the prevention campaigns - whether governmental or otherwise - against the use of legal and illegal drugs and that are part of these communication policies. Therefore, an understanding of how the consumption phenomenon reaches certain significances and how the campaigns express these significances is what this article proposes to achieve.

KEYWORDS: drugs; communications policies; campaigns; prevention; health promotion.

O fenômeno do consumo de drogas na sociedade contemporânea é tema de amplas discussões. No que diz respeito às políticas de comunicação para a saúde no Brasil, há uma gritante desconsideração das dimensões constitutivas deste fenômeno. Disto decorre que as condutas relacionadas à prevenção ao consumo de drogas envolvam esse consumo em significações marginais que, longe de propiciar uma sensibilidade para mudanças de comportamento, geram preconceito e segregação em relação ao usuário. Isto pode ser observado nas campanhas de prevenção - governamentais e não governamentais - ao uso de drogas lícitas e ilícitas, que são parte dessas políticas de comunicação. Compreender, portanto, como o fenômeno do consumo de drogas alcança determinadas significações e como as campanhas expressam estas significações é a proposta deste trabalho.

PALAVRAS-CHAVE: drogas; políticas de comunicação; campanhas; prevenção; promoção da saúde.

\footnotetext{
${ }^{1}$ Professora, Curso de Comunicação Social, Universidade Estadual de Santa Cruz, Ilhéus, Ba. <monica.benfica@uol.com.br>
} 


\section{O consumo das drogas}

É incontestável que o fenômeno do consumo de drogas na sociedade contemporânea vem ganhando uma visibilidade cada vez maior. Ele está presente na televisão, nos jornais e na internet. É tema de discussão em várias instituições que, ou buscam as causas e conseqüências de seu uso e propõem políticas para gerenciar um consumo adequado, ou investem em um trabalho de condenação, produzindo e reforçando uma significação marginal associada a essas substâncias. É importante lembrar que a noção de drogas envolve tanto aquelas chamadas de lícitas como as ilícitas. Além disso, apesar de seu consumo ser apreendido como o "problema das drogas", não se pode desconsiderar que sua produção, circulação e relação com o aparato do Estado são dimensões fundamentais, pois propiciam a construção de um governo paralelo caracterizado por violência, crime e corrupção.

Cientistas sociais que se dedicam à compreensão do fenômeno do consumo de drogas costumam afirmar que este não é contemporâneo e que a definição de drogas lícitas e ilícitas, legalidade ou ilegalidade, responde a determinadas formas de organização social. Em Las drogas: de los orígines a la prohibición, Antônio Escohotado (1994) aborda como, desde a Antiguidade, cada sociedade vai estabelecer com as drogas uma relação definida pelo que ele chama de "espírito do tempo". O trabalho de Escohotado é um indicador de como as referências históricas sobre o consumo de drogas pode ter um papel esclarecedor sobre as significações elaboradas pela sociedade atual sobre esse consumo. Neste artigo vamos utilizar o recorte correspondente à sociedade americana no século $\mathrm{XX}$, que se ajusta mais a nossos propósitos.

$\mathrm{Na}$ história das drogas levantada por Escohotado (1994), ele mostra como nos EUA, até 1900, todas as drogas conhecidas encontravam-se disponíveis em farmácias e drogarias, podendo também ser pedidas pelo correio. Isso acontecia em nível mundial, pois ocorria no restante da América, na Ásia e na Europa. As propagandas que acompanhavam esses produtos eram também livres e muito intensas, como as de qualquer outro produto. Não era um assunto jurídico, político ou de ética social ${ }^{2}$. Mas um proibicionismo, associado a um puritanismo em relação ao consumo de drogas, que vigorou nos EUA desde as primeiras décadas do século $\mathrm{XX}$, veio transformar a relação dessa sociedade com as drogas, fazendo florescer um comércio ilegal e, com ele, a corrupção e a instituição do crime organizado, em que começaram a vigorar o contrabando e a violência. A vigência da lei seca nos EUA, instituída em 1920, é um exemplo expressivo dessa relação, pois com ela veio, de acordo com o autor, o surgimento de meio milhão de novos delinqüentes e uma corrupção em todos os níveis. Em 1933, a lei foi revogada, compreendendo-se que ela produziu injustiça e hipocrisia. Associados à proibição do álcool estavam o ópio, a morfina e a cocaína. $O$ objetivo era acabar com todo uso não médico de tais substâncias. Estas mudanças trouxeram tanto o crime, como o aumento do consumo e uma mudança no perfil do consumidor ${ }^{3}$ : atualmente, nos EUA, a proibição, principalmente da heroína, propicia a perpetuação do crime organizado (Escohotado, 1994).

A história levantada por Escohotado vem ao encontro das idéias de

\author{
2 "Tras centenares de \\ comunicaciones en \\ revistas más ou menos \\ científicas, el joven \\ Sigmund Freud \\ empreende una \\ investigación global \\ con el fármaco, que \\ incluye autoensayos, \\ revisión de toda la \\ literatura existentey \\ propuestas de uso. \\ Parke Davis le pagará \\ en especie - quizá \\ también en metálico - \\ por declarar que su \\ cocaína es 'preferible' \\ a la de Merk, aunque \\ Freud aparece también \\ en prospecto de la \\ cocaína Merk loando el \\ producto". \\ (Escohotado, 1994, \\ p.79) \\ 3 "[...] si antes era en su \\ mayioría alguien de \\ clase media y con más \\ de cuarenta años, sin \\ historial delictivo, \\ ahora empieza a \\ concentrarse en gente \\ mucho más joven y \\ pobre, con \\ antecedentes penales $y$ \\ por eso mismo un \\ mejor acceso al \\ mercado \\ negro" (Escohotado, \\ 1994, p.94).
}


4 "[...]isso parece ter acontecido quando os anticoncepcionais por via oral foram introduzidos e muitas mulheres tiveram edemas, depressão, dificuldades vasculares e outros efeitos indesejados que ninguém, na época, atribuía à pílula". (Becker, 1977, p.186)
Gilberto Velho (1999) em seu trabalho."A dimensão cultural e política dos mundos das drogas", ao lembrar que "[...]quando se consome a droga em cada período se consome um significado diferente", insistindo ainda que a "[...] compreensão do fenômeno das drogas, assim como de qualquer outro, é passo indispensável a sua contextualização. Todas as tentativas de explicações genéricas, baseadas em premissas fisiológicas e psicológicas, tenderam a ficar no nível da rotulação e da estigmatização" (Velho, 1999, p.27). Uma outra referência é "La consumantion de tabac dans les processus de civilization", de Janson Hughes (2001), que explora, de maneira interessante, as diferentes significações que o consumo do tabaco ganha na Europa entre os séculos XVI e XX. Ele mostra como o consumo do tabaco e também as tecnologias associadas a seus usos tiveram funções terapêuticas, recreativas, de distinção de classes. O aumento ou declínio de seu uso vagam entre a instituição social de valores positivos $e$ negativos ligados ao seu consumo.

Uma das dimensões do fenômeno do consumo de drogas, muito pouco discutida, diz respeito aos efeitos das substâncias. Howard Becker (1977) define três cenários de uso de drogas: "o uso ilegal de drogas por prazer", "o uso de drogas receitadas medicamente" e a "ingestão involuntária de drogas por vítimas da guerra química". E chama atenção para o fato de que, quando uma pessoa ingere uma droga, sua experiência subseqüente é influenciada por suas idéias e crenças sobre aquela droga. O que ela sabe sobre a droga influencia a maneira como a usa, como interpreta seus efeitos múltiplos e responde a eles, e a maneira como lida com as conseqüências da experiência. No caso do uso ilícito de drogas por prazer, os efeitos da experiência dependem dos laços sociais e entendimentos culturais que surgem entre aqueles que usam a droga. Para Becker, enquanto o consumidor de drogas "ilícitas por prazer" encontra-se amparado com o controle sobre sua experiência, o consumidor de drogas lícitas receitadas por médicos não pode contar com este mesmo amparo. Este consumidor desconhece a ação das drogas no organismo não tendo, portanto, o domínio sobre seus efeitos. $\mathrm{O}$ autor faz referência a várias experiências com drogas lícitas que, ainda em fase de teste, são receitadas a pacientes e como seus efeitos colaterais são desconhecidos até pelo próprio médico ${ }^{4}$.

Assim, é possível compreender os efeitos das drogas como intrinsecamente ligados a um contexto social que produz e faz circular conhecimentos sobre determinada droga e que vai servir de guia para o consumidor. Estes dados levam Becker a insistir na importância dos canais de informação necessários para que estes conhecimentos circulem.

Nessa mesma perspectiva, Norman Zinberg (1980), em "The social setting as a control mechanism in intoxicant use", trata dos mecanismos de controle desenvolvidos no interior do meio social, que ele chama de sanções e rituais. Ele discute e faz ilustrações sobre os processos de aprendizado social pelos quais todos esses mecanismos se tornam ativos no controle do uso. A posição que ele defende é a de que uma decisão individual para o uso de uma droga, os efeitos que tem sobre o usuário $e$ as implicações psicológicas e sociais deste uso não dependem somente das propriedades farmacêuticas da droga $e$ das atitudes e personalidade do 
MARINHO, M. B.

usuário, mas também do meio social e físico em que tal uso tem lugar.

Quando se fala em sanções aplicadas ao uso de drogas ilícitas, a emergência dos conflitos entre controles sociais formais e informais é inevitável: enquanto as leis condenam o uso, o grupo social do usuário o aprova. Segundo o autor, devido a isso, surge a impossibilidade de uma educação formal para um uso controlado. Quando tal tentativa é feita, desemboca em um ardoroso insucesso, pois como falar de procedimentos adequados de consumo em uma cultura que não aceita o uso controlado das drogas ilícitas? Isto dificulta uma socialização centrada na família, nos meios de comunicação ou na escola. Resta assim, aos grupos de pares, a função de controlar o uso. O autor mostra, por meio de pesquisas, como uma série de procedimentos se torna parte da rotina de um "usuário controlado", que busca combinar o consumo de uma determinada substância com o desempenho de vários papéis sociais sem prejudicá-los. Todas essas formulações situam-se no campo da contextualização do consumo das drogas e seus efeitos. Mostram a importância da produção de espaços de comunicação para fazer circular informações sobre a natureza de determinadas substâncias e seu consumo adequado. Apontam, enfim, para uma compreensão não simplista, reducionista e moralista sobre o consumo de drogas.

\section{As políticas de comunicação}

As políticas e práticas institucionais relativas à questão das drogas vêm caracterizando-se como uma insistência de sucessivas ações em dois planos: o do consumo e o da produção/circulação. No primeiro plano, o do consumo, investe-se na condenação do usuário. Esta ação responde de forma positiva a uma opinião pública sempre pronta a formar juízos morais. Em "Problemas sociais, políticas públicas", Antônio Paixão (1994, p.134) afirma que

[...] a persistência do problema do tóxico, apesar dos altíssimos investimentos governamentais no combate a ele, parece não afetar o suporte público a políticas fracassadas de criminalização de usuários $e$ traficantes.

E, ainda, que as políticas "[...]respondem menos ao cálculo de custo $e$ benefício e mais a mitos ambientais sobre a droga como ingrediente de desordem" (Paixão, 1994, p.136). Assim, o problema do uso de drogas é deslocado para o plano da moralidade. No segundo plano, o da produção $e$ circulação, um enfoque considerado pelo autor pode ser esclarecedor:

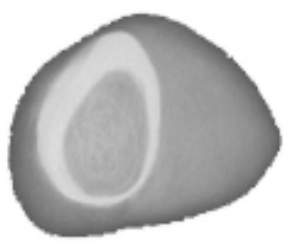

[...] tóxico é mercadoria e o equacionamento adequado do problema por ele representado pressupõe o conhecimento do mercado de produção, distribuição e circulação de drogas. Se o mercado é a 'instrumentalidade institucional' que monta o problema, portanto é o objeto a ser alterado pela legislação e pelas políticas públicas, quaisquer que sejam as justificativas mobilizadas. (Paixão, 1994, p.142)

Em relação ao mercado, o autor propõe a desregulamentação 
[...] já que os mecanismos convencionais de intervenção do estado em mercados criminosos (ampliação pela repressão, dos custos e riscos envolvidos no engajamento individual do crime) ali funcionam perversamente. (Paixão, 1994, p.140)
${ }^{5}$ O temo mídia aqui é usado em seu sentido mais amplo e refere-se não somente aos meios de comunicação de massa, mas a quaisquer meios de comunicação. Sobre a cultura das mídias e a crise da hegemonia da comunicação e cultura de massa, ver Santaella, 2002.
Interessa, aqui, a dimensão do consumo de drogas lícitas e ilícitas na forma como é apresentado pela mídia, e, de forma específica, como é problematizado pelas políticas de comunicação em saúde. É importante lembrar que hoje dificilmente um fenômeno está desvinculado da comunicação midiática. Como muito bem coloca Monclar Valverde (1996), nas sociedades complexas em que vivemos, não vivemos simplesmente a experiência da comunicação interpessoal. Os meios de comunicação têm uma dimensão planetária jamais experimentada por outra cultura. Emerge, assim, como primordial, a compreensão do "[...]papel dos media na formação e na transformação dos modos de significação que conferem sentido coletivo a nossas experiências" (Valverde, 1996, p.68). Isto leva à compreensão da mídia como experiência de nossa cultura. As palavras de Thompson (1998) expressam bem o significado dos meios de comunicação para o mundo moderno:

Se 'o homem é um animal suspenso em teias de significado que ele mesmo teceu' como Gertz uma vez observou, então os meios de comunicação são rodas de fiar no mundo moderno $e$, ao usar estes meios, os seres humanos fabricam teias de significação para si mesmos. (Thompson, 1998, p.20)

No campo da mídia ${ }^{5}$, onde o fenômeno do consumo de drogas ganha visibilidade, encontra-se uma comunicação, governamental e nãogovernamental, específica, voltada para a prevenção do consumo de drogas lícitas e ilícitas, que compõe as chamadas políticas de comunicação para a saúde.

As políticas de saúde - que se desenvolvem no país a partir da década de 20 do século XX com o campanhismo sanitarista - $e$ a comunicação para a saúde - que se impõe na década de 1960, com os preceitos desenvolvimentistas, como uma linha de investigação - têm um núcleo comum como alvo dos discursos críticos que ganham força $e$ visibilidade a partir da década de 1970, como reação ao modelo desenvolvimentista $e$ àqueles que vigoram na atualidade: o modelo unilinear que formata essas práticas (Natansohn, 2004; Pitta,1995; Teixeira, 1997). Uma reflexão sobre esse modelo remete, no que diz respeito à comunicação para a saúde, a algumas considerações sobre as teorias da comunicação que informam a comunicação no campo da saúde.

Se uma concepção unidirecional da relação Emissor/Receptor é a marca das incipientes teorias da comunicação vigentes nas décadas de 30 e 40 do século $\mathrm{XX}$, a trajetória das teorias da comunicação - que vigoraram entre 1930 e 1970, constituindo o campo das pesquisas sobre os meios de comunicação de massa - mostra que paulatinamente vão sendo consideradas 
variáveis, que se interpõem entre o emissor e o receptor, quebrando a linearidade do processo comunicativo e questionando o poder irrestrito do emissor. Assim, o receptor vai ganhando importância a partir do reconhecimento de sua complexa presença no processo comunicacional ${ }^{6}$. Nos anos 1980, as teorias da recepção se instituem no campo das teorias da comunicação, como demonstra o trabalho de Gomes (2000). A partir daí, vários estudos vêm contrariar uma concepção epistemológica "condutista" "[...] que faz da recepção unicamente um lugar de chegada e nunca um lugar de partida" (Martín-Barbero, 1995, p.41). Na década de 1990, às discussões sobre o campo da recepção como lugar de produção de sentido foram agregadas às reflexões sobre comunicação e saúde.

Buscando um distanciamento das concepções do processo comunicacional que acentua a importância seja do emissor ou do receptor nesse processo, propõe-se uma reflexão sobre o terreno da produção/ recepção das políticas de comunicação para a saúde, partindo da compreensão desse terreno como uma multiplicidade social na qual os discursos são tecidos. É essa tecitura que vai ser apropriada pelo modus operandi de determinadas mediações, que, enquanto produto, estará em relação com o espectador, de modo a gerar novos significados. Ainda sobre essa questão, como acredita Bougnoux (1994, p.51),

A relação pragmática ou de sujeito a sujeito impõe um certo limite intrínseco à influência. Há uma certa magia, uma feitiçaria da coletividade e da ação sobre as consciências que as modernas 'técnicas de comunicação' estão bem longe de dominar[...]

Se o processo comunicativo é entendido como fluxo, circularidade, na formulação autor a nenhum dos pólos é dada a capacidade de iniciar um processo comunicativo no sentido inaugural.

\section{As campanhas de prevenção}

Neste momento será dada atenção a um produto marcante das políticas de comunicação para a saúde, que são as campanhas de prevenção. Acredita-se que estas campanhas constituam espaços privilegiados para se dar conta de como os sentidos produzidos sobre determinado fenômeno articulam-se, são expressos e reelaborados constantemente nesses produtos. Geralmente, busca-se alcançar sua lógica partindo-se da idéia de que são atos comunicativos que se pautam por estratégias persuasivas em que se identifica um objetivo, que é o de obter um determinado efeito, sendo este a mudança de comportamento. Este procedimento, no entanto, deixa de lado algumas questões que, ao serem negligenciadas, impõem o risco de se trilhar por caminhos inconsistentes. Buscando evitar um olhar reducionista sobre essas campanhas, gostaria de lembrar que sua produção está impregnada de fluxos interativos contínuos em um campo social complexo. Em relação às campanhas públicas, uma questão muito importante a se considerar é que elas são apenas uma parte das ações de prevenção do Estado, embora uma parte muito significativa, pois a mais visível e a mais exposta. Geneviève Paicheler (2000), em um trabalho intitulado La

\author{
${ }^{6}$ Mauro Wollf (1994), \\ em um excelente \\ estudo sobre as teorias \\ da comunicação, traça a \\ trajetória dessas teorias \\ desde a década de 1930 \\ até a década de 1970. \\ Ele mostra como, no \\ seu desenvolvimento, a \\ dimensão da recepção \\ foi sendo cada vez mais \\ considerada na \\ produção das \\ mensagens veiculadas \\ pelos meios de \\ comunicação de massa. \\ A mensagem, no seu \\ percurso, encontraria \\ obstáculos a serem \\ transpostos como a \\ psicologia do receptor, \\ como concebia a teoria \\ empírico-experimental \\ ou da persuasão; ou a \\ cultura dos grupos, \\ identificada pela teoria \\ empírica de campo. A \\ primeira formulou suas \\ bases teóricas \\ apoiando-se no \\ desenvolvimento da \\ psicologia social $e$ a \\ segunda, na sociologia. \\ Estas teorias tiveram \\ como grande \\ representante \\ Lazarsfeld. É verdade \\ que, apesar de se \\ reconhecerem esses \\ obstáculos, essas teorias \\ pressupunham poder \\ superá-los mediante \\ estratégias corretas e \\ obter os efeitos \\ desejados.
}


${ }^{7}$ Sobre as estratégias das campanhas governamentais e não governamentais de prevenção a Aids veiculadas pela televisão brasileira, ver Marinho, 1999. comunication publique sur a sida en France: un bilan des stratégies et des actions (1987-1996), mostra como o engajamento do Estado na prevenção revela esta ação sob a perspectiva de duas ameaças: não apenas a insatisfação da população, mas sobretudo a de grupos significativos, podendo pesar sobre a opinião pública ou agir diretamente sobre o Estado, constituindo grupos de pressão. Isto demonstra que a comunicação pública é o viés pelo qual o Estado veicula informações, mas não deve ser encarada, unicamente, sob seu aspecto operacional. Ela se dirige a uma larga audiência que testemunha o interesse do Estado por um problema particular. E, ao extremo, pode substituir a ação. O Estado não controla as informações difundidas sobre determinado fenômeno que é tema de uma campanha. Às campanhas se juntam numerosas mensagens de uma multiplicidade de instituições e atores, difundidas pelos mais variados "meios". Os discursos transmitem as informações sobre determinado fenômeno, seus efeitos, meios de prevenção, enfim, veiculam uma visão de mundo. No entanto os poderes públicos não desconhecem a potencialidade da visibilidade. Ela aparece como fundamental, pois permite que a "opinião pública" "veja" o compromisso que esses poderes estabelecem em relação a determinados fenômenos, sua orientação, em função de suas obrigações. O fenômeno da Aids demonstrou muito bem isso. Em fins dos anos 1980 e nos anos 1990, as campanhas de prevenção da Aids veiculadas pela televisão colocaram em debate as estratégias de comunicação do governo ${ }^{7}$. As campanhas que tiveram como objetivo desenvolver estratégias preventivas, inicialmente foram criticadas por não abordarem as formas de redução de risco de uma maneira clara e apresentarem a proposta de abstinência sexual como a melhor forma de prevenção. Aliados a isso, revelavam-se sentimentos de medo e pânico somados a um desconhecimento da doença, que borbulhavam no interior da sociedade como um fato global, e que encontraram canal de expressão nessas campanhas. Ao colocarem em circulação a dimensão simbólica da doença - traduzida na associação da sexualidade e morte e de noções como a de grupo de risco -, as campanhas também foram acusadas de "gerar imagens distorcidas da doença e de suas vítimas alimentando preconceito e discriminação" (Parker, 1994, p.104).

As campanhas de prevenção ao consumo de drogas lícitas e ilícitas As palavras elucidativas de Aldous Huxley parecem oportunas para se dar início a uma reflexão sobre as campanhas de prevenção ao uso de drogas:
Nossa era, entre outras coisas, é a idade do automóvel e da
vertigem da velocidade. O álcool é incompatível com a segurança
nas estradas e sua produção, bem como a do tabaco condena
praticamente à esterilidade muitos milhões de hectares dos mais
férteis solos. Os problemas criados pelo álcool e pelo tabaco não
podem ser e isto não admite contestação - resolvidos pela
proibição. O impulso universal e permanente para a
autotranscendência não pode ser dominado pelo simples fechar
das tão solicitadas Portas na Muralha. (Huxley, 2001, p.36)

Interface - Comunic, Saúde, Educ, v.9, n.17, p.343-54, mar/ago 2005

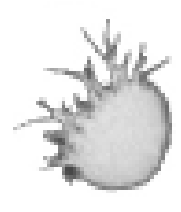

349 
Como já foi constatado, cada período estabelece com as drogas uma relação que vai ser definida por uma significação positiva ou negativa. No momento atual, insurge contra elas um verdadeiro movimento de interdição. As campanhas de prevenção ao uso de drogas, lícitas e ilícitas, para dar forma a uma intenção proibicionista têm utilizado elementos caracterizados pelo terror, dor e morte, que vêm evidenciar uma significação marginal das drogas.

Entre as campanhas de prevenção ao uso de drogas lícitas, as campanhas contra o cigarro ganharam um investimento fabuloso. Em 1965, o presidente Lyndon Johnson sancionou lei que obrigava a colocação de aviso na embalagem de cigarros, para advertir sobre os efeitos do fumo sobre a saúde. De lá para cá, ações do governo americano contra o cigarro se multiplicaram: espaços para fumantes foram restringidos, empresas produtoras de cigarro foram responsabilizadas por doenças causadas pelo fumo; buscam-se provas de que a nicotina causa câncer. Em 1999, Bill Clinton fecha o cerco contra as indústrias do tabaco, prometendo processar os produtores para ressarcir o governo federal dos gastos que teve com pessoas que adoeceram por causa do hábito do fumo.

Na Europa, em 1997, em uma situação contraditória, campanhas contra o cigarro estavam convivendo com a realidade da criação de empregos pela indústria do cigarro: naquele período, "[...]14 países já tinham banido totalmente as campanhas de cigarros da TV e do rádio". E, ainda, de acordo com analistas, não se pode garantir que a propaganda antifumo cumpriu seus objetivos. A queda do consumo do cigarro foi atribuída muito mais aos aumentos dos preços dos cigarros do que aos "US\$15 milhões anuais investidos no continente em campanhas para combater o hábito (ou o vício, como queiram) de fumar" (Aith, 2000).

Em 2002, o Parlamento Europeu aprovou uma medida:

Cada um dos países que compõem a UE poderá requisitar aos fabricantes que estampem no maço de cigarros fotografias chocantes, como de pulmões enfisematosos ou cânceres bucais, moléstias ligadas ao hábito de fumar. A advertência legal sobre os riscos do tabagismo, que hoje ocupa $4 \%$ da embalagem, deverá cobrir pelo menos $30 \%$ da frente do maço e $40 \%$ da parte posterior. (Brooke, 2000)

O Ministro da Saúde do Canadá no período, Allan Rock, é um dos fervorosos defensores dessa política. Pesquisas do governo canadense concluíram que

... maços com alertas com fotos têm sessenta vezes mais probabilidade de sensibilizar os fumantes do que as advertências usando apenas palavras. Embora o Canadá e a Califórnia já tenham exibido fotografias de pacientes com câncer em cartazes $e$ na TV, seria a primeira vez que fotos de tumores cancerosos seriam impressas em maços de cigarros. Não existe, entretanto, um consenso sobre a eficácia de tais imagens. Alguns analistas têm o bom senso de declarar que "as imagens chocantes não 
8 Da verba total de R\$ 55 milhões que o setor destina à publicidade, R\$ 33 milhões vão para as emissoras de televisão, R\$ 14 milhões para revistas e os R $\$ 8$ milhões restantes para painéis $e$ cartazes de rua.

${ }^{9}$ Tanto o Carlton como o Free patrocinavam festivais de dança (Carlton Dance) e de música (Free Jazz Festival).

\footnotetext{
${ }^{10}$ A organização já conta com mais de cinquenta filmes, alguns deles premiados nacional $e$ internacionalmente.
}

convencerão muitos fumantes a abandonar o cigarro. Uma das características da dependência é justamente desprezar os perigos associados ao vício. Por mecanismos ainda não bem conhecidos, o dependente, em nome do prazer agora, deixa de ligar para o que Ihe possa acontecer no futuro. (Folha de São Paulo, 2001)

Em 2000, o Ministério da Saúde do Brasil veicula a primeira contrapropaganda do cigarro: "'Cigarro faz mal até na propaganda' é o slogan da campanha do governo, que custou $R \$ 4,5$ milhões" (Folha de São Paulo, 2000). Aqui, inicia-se uma obsessiva luta contra o cigarro que ganha o estatuto público de droga. Nesse mesmo ano, foi elaborado pelo Ministério da Saúde um projeto de lei que proíbe a propaganda de cigarros na televisão, na imprensa e na rua $^{8}$. Como o veto total das propagandas contraria a Constituição, que estabelece que poderá haver publicidade de agrotóxicos, bebidas alcoólicas e cigarros, desde que com restrições, o projeto admite a exibição de pôsteres e cartazes de propaganda em recintos fechados. Outra proibição prevista no projeto de lei diz respeito aos produtores de cigarro enquanto patrocinadores de eventos esportivos $e$ artísticos". "O objetivo da campanha e do projeto é evitar que os fabricantes de cigarro continuem a fazer propaganda enganosa, a vender ilusões e a viciar adolescentes e jovens', diz Serra", ministro da Saúde no governo de Fernando Henrique Cardoso (Serra, 2001). Seguindo a trilha da União Européia, o governo brasileiro institui, em 2002, a obrigação de que maços de cigarro estampem fotos coloridas de doentes afetados pelo cigarro seguidas de "mensagens duras". No Brasil, a campanha dos maços de cigarro - a campanha mais recente - tem como temas o câncer do pulmão, o infarto, o fumo na gravidez, a nicotina como droga que causa dependência, a impotência sexual, o adulto como responsável pela disseminação do vício entre as crianças.

Entre as campanhas de prevenção ao consumo de drogas ilícitas, destacam-se as veiculadas pela televisão. Ao contrário das campanhas contra o cigarro, elas têm as Organizações Não-Governamentais como seus maiores investidores. A Associação Parceria Contra Drogas pode ser considerada uma das organizações mais presentes na televisão. Constituída por empresários de vários setores da iniciativa privada ela está em operação desde abril de 1996.

\footnotetext{
As agências de propaganda criam voluntária e gratuitamente as campanhas. A mídia cede tempo e espaço, sem custos, para a veiculação das mensagens. $E$ as empresas colaboram com recursos financeiros, que se destinam a pagar os inevitáveis custos de produção dos anúncios para TV, rádios, jornais, outdoor e revistas"10. (UOL, 2004)
}

O símbolo visual da organização é uma mão branca espalmada sobre um losângulo vermelho. Esta imagem remete a idéia de "Pare, não ultrapasse o limite da segurança da experiência sem drogas".

Textos carregados de ameaças e acusações, slogans de alerta e imagens 
aterrorizantes são elementos característicos das campanhas de prevenção ao uso de drogas ilícitas produzidas e veiculadas nos últimos anos. Faz-se uma ressalva à campanha que vem tentando, de forma simplista e estereotipada, propor a prevenção, abordando o consumidor como o culpado da violência gerada pelo tráfico de drogas. Essa questão é um excelente exemplo de como a questão das drogas no Brasil vem sendo tratada de forma a não se olhar uma questão crucial, que é a de como historicamente a proibição perpetuou o crime organizado e gerou violência.

Não é a proposta, aqui, analisar a eficácia das campanhas governamentais e não-governamentais de prevenção de drogas lícitas e ilícitas. Pois, como muito bem coloca Paicheler (2000), dar conta da eficácia de uma campanha é uma tarefa escorregadia, porque, em primeiro lugar, é impossível separar as campanhas de um contexto complexo em que numerosas comunicações, em diferentes níveis, se entrelaçam. E, também, os efeitos da comunicação para prevenção ao uso de drogas não são imediatos, eles só podem ser analisados a longo prazo, sem que seja possível separar o que pode ser atribuído positivamente às campanhas propriamente ditas. Freqüentemente, os estudos dos efeitos da comunicação se fazem por meio de sondagens, buscando mensurar a eficácia da mensagem. Procura-se, geralmente, saber se ela cumpriu seu objetivo, se foi ou não passada sem encontrar oposições ou resistências. Os limites de tais sondagens não permitem ir além de situações externas, não alcançando dimensões que indiquem uma real compreensão do problema.

O que importa aqui é evidenciar a questão que diz respeito à maneira como a droga pode ser considerada um fenômeno resultante de diferentes construções de sentido, realizadas pela estratégia de várias instituições: médicas, políticas, religiosas, policiais etc. Ela ganha visibilidade e face próprias à medida que vai sendo publicizada, principalmente pelas notícias e campanhas (Fausto Neto, 1999). Por enquanto, a medida deste trabalho permite arriscar, em um primeiro momento, que o fenômeno do uso de drogas não pode ser compreendido fora de um campo histórico e social no qual um sentido dominante sobre as drogas é construído a partir de interesses de várias instituições e da visibilidade que consegue alcançar. Em segundo, as políticas de comunicação preventiva e, de forma mais específica, as campanhas são objetivações privilegiadas que expressam e renovam este sentido social dominante. Questionar, pois, este sentido, foi o intuito deste trabalho.

\section{Referências}

AITH, M. Indústria do fumo tem vitória nos EUA. Folha de São Paulo, São Paulo, 22 mai. 2000. Editoria Cotidiano, p.c3.

BECKER, H. Consciência: poder e efeitos da droga. In: BECKER, H. (Org.) Uma teoria da ação social coletiva. Rio de Janeiro: Zahar, 1997. p.180-204.

BOUGNOUX, D. Introdução às ciências da informação e da comunicação. Trad. Guilherme João de Freitas. Petrópolis: Vozes, 1994.

BROOKE, J. Canadá quer fotos de câncer no maço. Folha de São Paulo, São Paulo, 14 mai. 2000. Editoria Mundo, p.A13.

ESCOHOTADO, A. Las drogas: de los orígenes a la prohibición. Madrid: Alianza Editorial, 1994. 
FAUSTO NETO, A. Comunicação e mídia impressa: estudo sobre Aids. São Paulo: Hacker, 1999. (Coleção Comunicações)

FOLHA DE SÃO PAULO. Maço ilustrado. Folha de São Paulo, São Paulo, 18 mai. 2001. Editoria Brasil, p.A18. (sem autor)

GOMES, I. M. M. Efeito e recepção: a interpretação do processo receptivo em duas tradições de investigação sobre os mídias. 2000. Tese (Doutorado) - Faculdade de Comunicação, Universidade Federal da Bahia, Salvador.

HUGES, J. La consumation de tabac dans le processus de civilisation. In: BECKER, H. (Org.). Qu'est-ce qu'une drogue? Anglet: Atlantica, 2001. p.69-95.

HUXLEY, A. As portas da percepção. Trad. Osvaldo de Araújo Souza. São Paulo: Globo, 2001.

MARINHO, M. B. Da ameaça à sedução: estudo sobre as campanhas de prevenção da Aids veiculadas pela televisão. 1999. Dissertação (Mestrado) - Faculdade de Comunicação, Universidade Federal da Bahia, Salvador.

MARTIN-BARBERO, J. América Latina e os anos recentes: o estudo da recepção em comunicação social. In: SOUSA, M. W. (Org.) Sujeito, o lado oculto do receptor. São Paulo: Brasiliense, 1995. p.35-56.

NATANSOHN, G. Comunicação e Saúde: interfaces e diálogos possíveis. Rev. Econ. Política de Las Tecnologias de la Información y Comunicación, v.6, n.2, 2004. Disponível em: <http:// www.eptic.com.br>. Acesso em: 25 jan. 2005.

PAICHELER, G. La comunication publique sur la sida en France: un bilan des stratégies et des actions (1987-1996). Paris: CERMES/ANRS, 2000.

PAIXÃO, A. Problemas sociais, políticas públicas. In: ZALUAR, A. (Org.) Drogas e cidadania: repressão ou redução de riscos. São Paulo: Brasiliense, 1994. p.129-45.

PARKER, R. A construção da solidariedade. Rio de Janeiro: Relume Dumará: ABIA/ IMS/UERJ,1994.

PITTA, A. (Org.) Saúde e Comunicação: visibilidades e silêncios. São Paulo: HUCITEC, 1995.

SANTAELLA, L. A crítica das mídias na entrada do século XXI. In: PRADO, J. L. (Org.) Crítica das práticas midiáticas: da sociedade de massa às ciberculturas. São Paulo: Hacker, 2002. p.44-56.

SERRA, J. O cigarro e as pedras. Folha de São Paulo, São Paulo, 4 jun. 2001. Editoria Brasil, p.A10.

TEIXEIRA, R. Modelos comunicacionais e práticas de saúde. Interface - Comunic., Saúde, Educ., v.1, n.1, p.7-40,1997.

THOMPSON, J. A mídia e a modernidade: uma teoria social da mídia. Petrópolis: Vozes, 1998.

UOL. ASSOCIAÇÃO PARCERIA CONTRA DROGAS. Disponível em: <http://www.uol.com.br/ parceriacontradrogas. Acesso em: 02 dez. 2004.

VALVERDE, M. Experiência e comunicação.Textos de Cultura e Comunicação, n.35, p.65-73, 1996.

VELHO, G. A dimensão cultural e política do mundo das drogas. In: ZALUAR, A. (Org.) Drogas e cidadania: repressão ou redução de riscos. São Paulo: Brasiliense, 1999. p.23-30.

WOLF, M. Teorias da Comunicação. Lisboa: Presença, 1994.

ZINBERG, N. The social setting as a control mechanism in intoxicant use. In: ZINBERG, $\mathrm{N}$. Theories on drug abuse: select contemporary perspectives. Monograph, 30 march 1980. Xerocopiado.

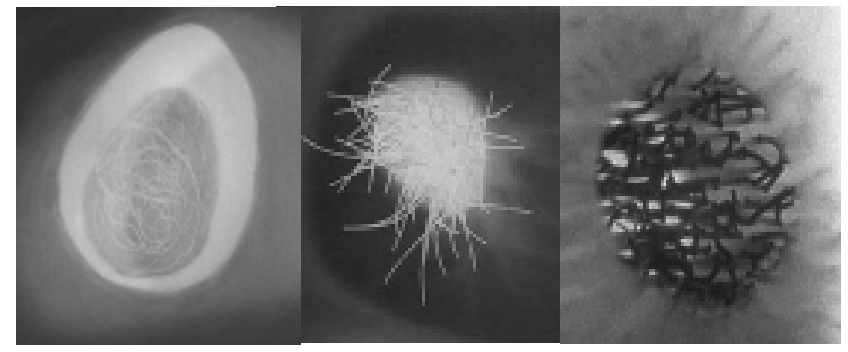

Interface - Comunic, Saúde, Educ, v.9, n.17, p.343-54, mar/ago 2005 
MARINHO, M. B.

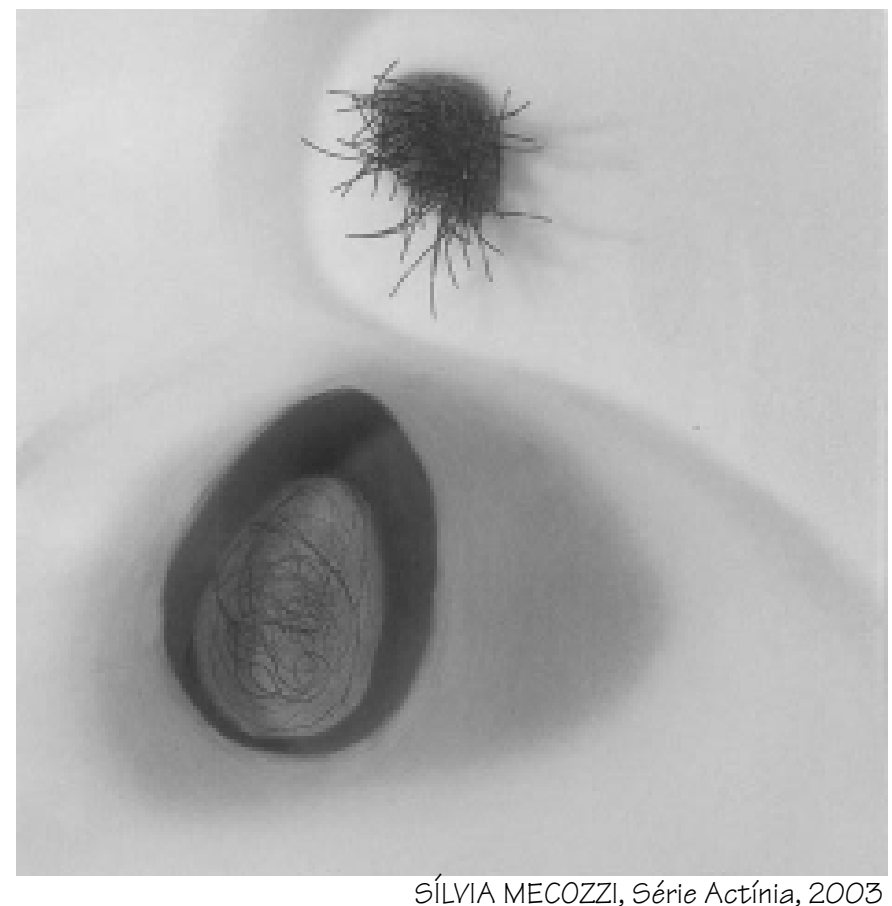

MARINHO, M. B. El demonio en los "paraísos artificiales": consideraciones sobre las políticas de comunicación para la salud relacionadas al consumo de drogas. Interface - Comunic., Saúde, Educ., v.9, n.17, p.343-54, mar/ago 2005.

El fenómeno del consumo de drogas en la sociedad contemporánea es tema de amplias discusiones. En Brasil, en las políticas de comunicación para la salud hay una ostensiva desconsideración de las dimensiones constitutivas de este fenómeno. De allí que las conductas relacionadas a la prevención del consumo de drogas revistan a ese consumo de significaciones marginales que, en lugar de despertar una sensibilidad que propicie los cambios de conducta, generan prejuicios y segregación con relación al usuario. Esto puede observarse en las campañas - gubernamentales y no gubernamentales - de prevención del uso de drogas lícitas e ilícitas que integran esas políticas de comunicación. Por lo tanto, la propuesta de este trabajo es comprender cómo el fenómeno del consumo de drogas alcanza determinadas significaciones y cómo las campañas expresan estas significaciones.

PALABRAS CLAVE: drogas; políticas de comunicacíon; campañas; prevención; promoción de la salud. 